\title{
Cirque du Soleil
}

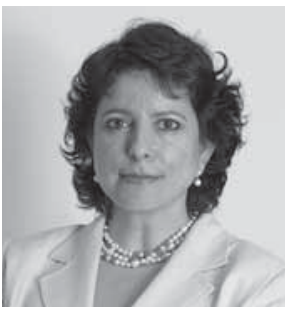

Roseli Morena Porto FGV-EAESP
$\mathbf{N}$

o início de agosto estreou em São Paulo o espetáculo Saltimbanco, do Cirque du Soleil. A proveitando essa oportunidade, a FGV-EAESP convidou Mario D'Amico, diretor de Marketing do Cirque, para uma visita à Escola. Ele nos falou sobre o modelo de gestão da companhia canadense que revolucionou o entretenimento e faturou US\$ 700 milhões em 2005.

São 3 mil funcionários de 40 países diferentes falando 25 idiomas. De seus artistas, 34 são brasileiros. Seus produtos rompem barreiras culturais. Atualmente são 11 shows itinerantes mundiais e seis residentes, sen do um em O rlando e cinco em Las Vegas. Os relacionamentos interculturais são simples quando comparados à complexa logística eaos detal hes da montagem de um espetáculo itinerante. São utilizados 80 caminhões para transportar tendas, cenários e figurinos. É preciso lidar com questões como visto de entrada, idioma, moeda e demais diferenças culturais para as 150 pessoas que compõem cada espetáculo.

o Cirque se tornou objeto de estudo de administradores, além de um fenômeno artístico mundial. Começou com um negócio pequeno, em 1984, idealizado por Guy Laliberté, ex-músico e engolidor de fogo, seu atual presidente. Seu sonho era percorrer 0 mundo e se divertir fazendo isso. Conforme suas palavras, o core business de sua empresa "gira em torno da investigação de novas formas de entrar em contato com o público e tocá-lo, tendo sempre em vista a sua própria reinvenção". N um momento em que o setor se encontrava em declínio, ameaçado principalmente pelas diversões el etrônicas e elevados custos de logística, sobretudo pela manutenção de animais, el e abriu um novo mercado. Integrou os componentes do circo em um tema único para contar uma estória com início, meio e fim. Redefiniu o conceito para criar algo diferente com elementos da ópera e balé. Hoje ele e sua equipe se posicionam como criadores de conteúdo, distribuídos em vários formatos: $C D$, DVD, programas para TV, shows e bares temáticos em cruzeiros marítimos.

Apesar de sua origem artística, o segredo do sucesso parece estar na sua capacidade de manter um tenso equilíbrio entre arte e negócio. Como conseguem isso? Permeando toda a organização com a integração desses dois mundos a princípio incompatíveis. $\mathrm{Na}$ sede, em Montreal, suas salas de reunião são identificadas pelos nomes dos espetáculos, e daí seus executivos acompanham os ensaios dos acrobatas, enquanto definem novos destinos ou recebem patrocinadores. Também confeccionam anual mente milhares de peças de vestuário e sapatos, em regime artesanal. Mais do que combinar opostos, o Cirque conseguiu perpetuar a essência e a magia do início de suas atividades. Perfeitamente possível para empresas de qualquer setor. 